\title{
Data Analysis System for Population and Family Studies on Japan in the 17th-19th Centuries
}

\author{
KAWAGUCHI Hiroshi
}

\section{Introduction}

II Structure of the System

III Data Analysis System for the Religious Investigation Registers

(1) Source Documents

(2) Database

(3) Application Programs

IV Data Analysis System for the Buddhist Temple Death Registers
(1) Source Documents
(2) Database
(3) Application Programs

V Data Analysis System for the Household Registers

(1) Source Documents

(2) Database

(3) Application Programs

VI The Alliance Project for Kinship and Genealogy

VII The Historical GIS Project for Geographic Mobility

VIII Geographic Use of the System : Regional Difference in Women's Age at Marriage

IX Conclusion

Key Words : religious investigation register, Buddhist temple death register, household register, genealogy, database, historical GIS

\section{Introduction}

The total population in Japan remained stable during the 18th century and started to increase in the 1840s until 2004. Especially, the population in northeastern Japan had started to decrease from the beginning of the 18th century. The lowest population level is found from the 1780s until the 1840s, and it started to increase after that period. In northeastern Japan, structural changes occurred at the beginning of the 19th century and the population increase from the $1840 \mathrm{~s}$ is thought to be one of the significant signs announcing the onset of modern industrial society in Japan.

However, at present the reasons why the population started to increase in the 1840s are not yet entirely clear. On the other hand, some historical demographers have pointed out regional differences in the life-paths of the peasants. Therefore, it is necessary to find historical documents concerning population and family patterns from all over the country and to place the 
micro studies of each village in a nationwide perspective. In order to collect, store, and analyze historical handwritten documents, it has become urgent to develop a database system and share it with researchers.

Most studies on population and family patterns in early modern Japan draw their sources from three kinds of historical documents. These are the religious investigation registers generally called Shumon-Aratame-Cho, the Buddhist temple death registers known as Kako-Cho, and the household registers called Koseki. In cases where these handwritten documents have been well preserved, it is possible to obtain a considerable amount of information about the peasants' real life including not only population statistics, but also indices concerning family status.

During the second half of the1960s, Professor Akira Hayami applied the family reconstitution method developed in France to calculate demographic statistics with parish registers, in order to investigate the Japanese religious registers. His work laid the foundation of serious research work on historical demography in Japan, as family reconstitution based on the religious investigation registers allowed demographic analysis and reconstitution of the peasants' life-paths. Therefore, family reconstitution with the help of the Japanese religious investigation registers has been an important methodological landmark in historical demography.

We have been developing a database system to calculate demographic statistics from these historical documents since 1986, in order to establish an automatic procedure for family reconstitution. The system is called DANJURO (Data ANalysis system for population and family studies in Japan Using the Relational database Of historical documents). DANJURO version 1.0 was the first computer system in the world to achieve unification of data processing by storing the religious investigation registers for calculation of demographic statistics. We developed the system with a relational database management system on a mainframe computer and stored the data in kanji (Chinese character) code. Other Japanese systems followed the basic plans adopted in our system and thus improved input interfaces.

A recent version of the DANJURO system will allow us to improve four technical problems : to reduce data processing to output demographic statistics and indicators, to ensure the reliability of the data processing, to preserve historical documents in digital form, and to share the data and data analysis method with researchers around the world.

This paper aims at presenting a comprehensive report on our data analysis system for historical documents in early modern Japan. The study comprises nine parts. After the Introduction, Chapter II presents the structure of the DANJURO system. Chapter III deals with the data analysis system for the religious investigation registers. Chapter IV describes the data analysis system for the Buddhist temple death registers. Chapter V reports the data analysis system for the household registers. Chapter VI explains the Alliance project for genealogy. Chapter VII presents the historical GIS for internal migration. Finally, Chapter VIII examines the regional differences of reproductive behavior based on a geographic use of the DANJURO system, followed by the Conclusion.

\section{Structure of the System}

DANJURO version 4.0 is composed of six parts: (i) data analysis system for the religious investigation registers, (ii) data analysis system for the Buddhist temple death registers, (iii) data analysis system for the household registers, (iv) technology to recognize handwritten characters in historical documents with neural network, (v) research funds, publication of 




Figure 1. DANJURO Index Window

research results, and prizes (vi) links to related sites. The URL of DANJURO is http : // kawaguchi. tezukayama-u. ac. jp. Figure 1 is the index window of DANJURO.

DANJURO version 4.0 is a server-client web system with two layers of servers : the database server and the application server. We have developed the system with Oracle Database 10.2.0.1.0 for Microsoft Windows 2003 on HP Proliant ML150 G3 as the database server and Oracle Application Server 10.1.3.3.0 for Windows 2003 on HP Proliant ML150 G3 as the application server. To get access to this system, users need to install web browsers such as Internet Explorer 6.0, 7.0, or Firefox 3.5 in their personal computers. Also, users also have to install Excel 2003 or 2007 to execute the application programs.

As DANJURO has stored up a large amount of private information recorded more than 100 years ago, the organization committee for DANJURO's management intends to protect personal data from unintended use. The organization committee always checks the application forms from researchers wishing to use the system and assigns new accounts. Users of this system are required to input their user name and password in some authentication dialog boxes. As we have obtained formal permission from owners of the religious investigation registers to share the data with researchers through DANJURO, we have given access to users of the data analysis systems for the religious investigation registers through the Internet. We open the data analysis system for the Buddhist temple death registers and the household registers, only after obtaining permission from the owners of these registers. Therefore, the organization committee has restricted the right of access to certain parts of DANJURO where formal permission has not been obtained. 


\section{Data Analysis System for the Religious Investigation Registers}

\section{(1) Source Documents}

One of the most important documents for historical demography or family history concerning early modern Japan is the religious investigation register called Shumon-Aratame-Cho or Ninbetsu-Aratame-Cho. In general, these registers recorded the entries annually, during a period of over 150 years since the end of the 17th century, in villages and towns throughout Japan. For example, in Aizu County and Ohnuma County located in the province of Mutsu, each village head kept the religious investigation registers-Shumon-Aratame-Ninbetsu-Iebetsu-Cho-once a year, from 1694 or 1695 until 1869.

In the religious investigation registers in Aizu and Ohnuma, the records for each person comprise the following information : name, age, relationship with the household head, and change in family status. Household records include the following information: number of cattle and horses, size of the house, roofing material, yield of cultivated land, religious sect, family temple, place of the family temple, and household size. In cases where the annual religious investigation registers have been well preserved, we can obtain a considerable amount of information about the peasants' real life including population statistics such as sex ratio, crude death rate, age at first marriage, etc. It is also possible to get indices concerning family status such as household structures, inheritance patterns, adoption systems, etc.

When we analyzed the religious investigation registers in Aizu and Ohnuma, we found that the actual persons living in the villages were recorded in the registers by household. Changes in family status such as marriage, adoption, apprenticeship, etc. were registered within the year. As each village head updated the register once a year, miscarriage, stillborn and neonate babies were not registered. Consequently, the numbers of births and deaths was probably underestimated. Also, brides and bridegrooms who married and divorced within the year were probably not recorded either. It is also impossible to count the number of seasonal laborers from the registers. It should be noted that data concerning the size of the house are different from the data resulting from reconstruction work undertaken by some architectural historians.

Although the Japanese religious investigation registers have an established value among the historical demographers in the world, some historians stress that calculation of population statistics based on these registers should be made with great care. That is the reason why we have strongly pointed out to historical demographers the importance of proper understanding of the registers and registration systems. Moreover, local differences in these registers should also be taken into consideration.

\section{(2) Database}

We have collected about 102,000 personal data and 23,000 household data of seven villages (Table 1).

The database of the religious investigation registers is composed of four tables : personal information table, household information table, digital image table, and bibliography table. All data are in UTF-8 Character Set. Items in bold letters represent numerical values, while underlined items are digital images of the registers; other items are recorded in kanji (Chinese characters) code.

1) Personal information table 
Table 1. Religious Investigation Registers in DANJURO

\begin{tabular}{l|c|c|c}
\hline \multicolumn{1}{c|}{ Village/county/province } & Year & Person-year & Household-year \\
\hline Ishibuse village, Aizu County, Mutsu province & $1752-1812$ & 11,593 & 2,321 \\
\hline Komatsukawa village, Aizu County, Mutsu province & $1792-1868$ & 7,338 & 1,771 \\
\hline Tounosu village, Aizu County, Mutsu province & $1790-1859$ & 18,155 & 4,349 \\
\hline Kuwanohara village, Ohnuma County, Mutsu province & $1750-1834,1840-1858$ & 11,486 & 2,518 \\
\hline Nakatou village, Tama County, Musashi province & $1843-1864$ & 12,096 & 1,997 \\
\hline Kami-Kawarabayashi village, Muko County, Settsu province & $1750-1819$ & 20,304 & 4,526 \\
\hline Hanakuma village, Yatabe County, Settsu province & $1789-1869$ & 20,822 & 5,313 \\
\hline \multicolumn{1}{c|}{ Total } & & $\mathbf{1 0 1 , 7 9 4}$ & $\mathbf{2 2 , 7 9 5}$ \\
\hline
\end{tabular}

Village/county/province, year, household ID number, personal ID number, name in Roman letters, name in Chinese characters, sex, age, relationship with the household head, marital status, religion, place of the family temple, family temple, change in family status, details of changes in family status, official status in the village.

2) Household information table

Village/county/province, year, household ID number, name of the household head in Roman letters, name of the household head in Chinese characters, number of male kin members, number of female kin members, number of hereditary male servants, number of hereditary female servants, number of male servants, number of female servants, number of male lodgers, number of female lodgers, household size, structure of household, existence of other persons in addition to the kin members, generations living together, number of cattle, number of horses, yield of cultivated land, size of the house, roofing material.

3) Digital image table

Village/county/province, year, household ID number, digital image of the registers by household.

4) Bibliography table

Village/county/province, year, date of the investigation according to the Japanese old lunar calendar, title of the register, name of the person who made the investigation, owner of the registers, institution preserving the registers, digital image of the cover, digital image of the colophon.

The user interface of the database comprises nine windows: (i) Index window, (ii) Input for retrieval conditions window, (iii) Browsing window, (iv) Personal information form, (v) Household information form, (vi) Digital image form, (vii) Bibliography form, (viii) Selection of download items window, (ix) Download window.

When users click on the Shumon-Aratame-Cho image database in the Index window, the Input for retrieval conditions window appears, where they can input retrieve conditions. By clicking on the Search button at the bottom of the Input for retrieval conditions window, the retrieval program is executed and the Browsing window appears on the screen, where users can confirm the retrieval key words, the number of hit data and 20 cases of retrieval results per page.

If users click on ID on the left side of the Browsing window, a Personal information form will open. Users can look at the Household information form, Digital image form and Bibliography form by clicking on the Personal information form button. If users wish to check whether the 


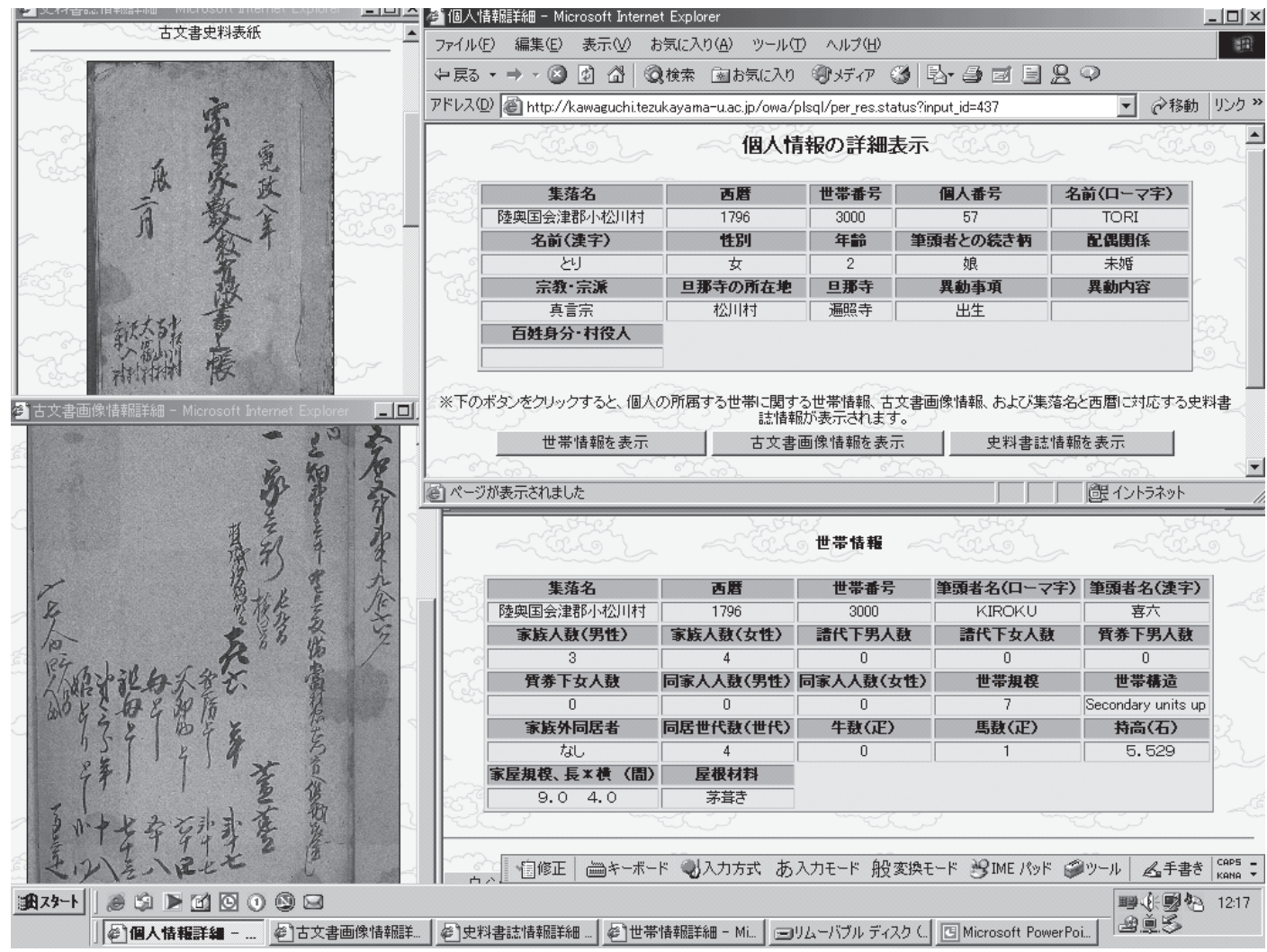

Figure 2. Personal Information Form, Household Information Form, Digital Image Form and Bibliography Form

database builder misread or not the old registers or would like to see some digital images such as layout, handwriting or seal impression, they can compare character data in the Personal information form and the Household information form with image data in Digital image form, as well as the corresponding Bibliography form in the same screen (Figure 2). Our purpose is to guarantee the reliability of the data processing by means of digital images of the registers.

A click on the Selection of download items button in the Browsing window allows users to reach the Selection of download items window. By clicking on the Go to download window at the bottom of the Selection of download items window and clicking after on the Download button in the Download window, users can obtain the retrieval results in C. S. V. form data.

\section{(3) Application Programs}

The application programs provide 62 demographic statistics and indicators as follows :

1) Population increase indicators

Population change, number of households, annual rate of population growth, number of cattle and horses

2) Birth and death indicators

Number of births, crude birth rate, sex ratio at birth, general fertility rate, child-woman ratio, women's age at birth, number of births per woman, number of deaths, crude death rate, sex ratio at death, age at death, crude rate of natural increase.

3) Marriage and migration indicators 
Number of married persons, age at marriage, age at first marriage, number of marriages per person, number of out-migrants, out-migration rate, number of in-migrants, in-migration rate, net migration rate.

4) Other indicators

Number of servants, age at service, number of name changes, age at name change, number of name changes per person, number of adoptions, age at adoption, number of household heads, age when a person becomes household head.

5) Population structure indicators

Mean age, population by five-year age groups, percentage of population by five-year age groups, population aged 14 and under, 15-59, 60 and above, percentage of the population aged 14 and under, 15-59, 60 and above, age dependency ratio, sex ratio, sex ratio of the population aged 14 and under, 15-59, 60 and above, population by marital status, percentage of married persons and percentage of single persons, population by religion, percentage of population by religion.

6) Household structure indicators

Household mean size, number of households by household size, percentage of households by household size, number of households by yield of cultivated land, percentage of households by yield of cultivated land, relationship between household size and yield of cultivated land, number of households by household structure, percentage of households by household structure, number of households with servants or lodgers, percentage of households with servants or lodgers, number of households by generations living together, percentage of households by generations living together, number of couples per household, number of households with cattle or horses, percentage of households with cattle or horses.

The user interface for the application programs consists of three windows : the Application program window, the Input for retrieval conditions window, and the Data download window. The Application program window appears with a click on Application program in the Index window. In order to execute the application program, it is necessary to download a macro file and a data file into the computer. First, users have to click on the floppy disk logo on the left side of each indicator and the macro file will be downloaded in the drive. Then a click on the underlined indicator in the Application program window opens the Input for retrieval conditions window. By clicking on the Search button in the Input for retrieval conditions window, retrieval and calculation is executed and the Data download window appears on the screen. C. S. V. form data is obtained by clicking on the Download button in the Data download window. If users execute the macro file in the computer specifying the data file, they can obtain a graph of the corresponding demographic indicator. The algorisms to calculate the indicators are explained in the Input for retrieval conditions window. Also, users can check the macro program themselves. We also ensure the reliability of the data processing by means of access to the algorism and program to all the users of our program.

\section{Data Analysis System for the Buddhist Temple Death Registers}

\section{(1) Source Documents}

Another important document for historical demography concerning early modern Japan is the Buddhist temple death register called Kako-Cho. Most Japanese Buddhist temples keep death registers for their members. There are two types of death registers : by chronological order or by 
date of death, the latter usually being the basic type of registration; chronological registration is compiled from the latter, too. Buddhist priests usually hold a daily ritual ceremony for the dead using death registers by date of death.

In both types of temple death registers, records mention the secular name or the family relationship to the chief mourner, the posthumous Buddhist name given to the deceased person by the Buddhist priest, and the date of death. In a few cases, age at death, address, and date of birth are also registered. The cause of death, birthplace, and death place of the dead are seldom written.

Research on the characteristics of the Buddhist temple death registers has just started. It is impossible to obtain data about 'at-risk population' from these registers such as the total population concerning the members of the family temple, the population by age groups or the population by sex. Therefore, it is necessary to undertake further studies on this kind of registers for better understanding of population and family patterns. We have to verify the relationship between the members and the family temple such as the geographic distribution of the members of the temple, the date when miscarriage, stillbirth, neonate and infant deaths started to be recorded in the registers with the posthumous Buddhist name, and the meaning of the posthumous Buddhist name. Also, it is important to compare the temple death registers with the religious investigation registers and the tombstones.

In general, according to the last words of the posthumous Buddhist name, Buddhist priests probably attempted to divide the dead into three age-groups : neonates including miscarriages and stillbirth babies, children under fourteen years old, and adults from fifteen years of age and above. However, we should bear in mind that neonates, miscarriages and stillbirths were not always recorded in these registers before 1880 .

Many Buddhist temples prohibited opening the temple death registers for over twenty years, in order to protect private information. Therefore, research works using the Buddhist temple death registers have decreased since the 1980s. Nevertheless, these registers are important to estimate the victims of disasters such as eruption of volcanoes, cold weather, epidemics, etc. The death registers are the only documents that have been kept from the end of the 17th century until the present without interruption.

\section{(2) Database}

We have collected data concerning 13 Buddhist temple death registers and stored up approximately 34,000 deaths data (Table 2 ).

In the database of the Buddhist temple death registers, all data are in UTF-8 Character Set. Items in bold letters represent numerical values and the other items are recorded in kanji (Chinese characters) code as follows :

1) Personal information table

Village/county/province where the temple is located, name of the temple, Buddhism sect, title of the temple death registers, year of death, date of death in Japanese old lunar calendar, date of death in the Gregorian calendar, posthumous Buddhist name, sex, address, secular name, age at death, birth year, date of birth in Japanese old lunar calendar, date of birth in the Gregorian calendar, cause of death, place of death, birthplace.

The user interface of the database comprises six windows: Kako-Cho database window, Input for retrieve conditions window, Browsing window, Personal information form, Selection of download items window, and Download window. 
Table 2. Buddhist Temple Death Registers in DANJURO

\begin{tabular}{l|c|c|c}
\hline \multicolumn{1}{c|}{ Village/county/province } & Temple & Year & Number of deaths \\
\hline Kawasaki village, Tama County, Musashi province & Temple A & $1736-1910$ & 2,608 \\
\hline Shimo-Ishihara village, Tama County, Musashi province & Temple B & $1579-1910$ & 1,631 \\
\hline Itsukaichi village, Tama County, Musashi province & Temple C & $1278-1910$ & 2,542 \\
\hline Chigase village, Tama County, Musashi province & Temple D & $1786-1910$ & 2,207 \\
\hline Uchikoshi village, Tama County, Musashi province & Temple E & $1494-1910$ & 2,045 \\
\hline Hamura village, Tama County, Musashi province & Temple F & $1646-1910$ & 2,413 \\
\hline Hino town, Tama County, Musashi province & Temple G & $730^{*}-1910$ & 4,939 \\
\hline Hamura village, Tama County, Musashi province & Temple H & $1683-1910$ & 2,906 \\
\hline Fukushima village, Tama County, Musashi province & Temple I & $1364-1910$ & 2,491 \\
\hline Yokozawa village, Tama County, Musashi province & Temple J & $1550-1804$ & 2,601 \\
\hline Shinjou village, Maniwa County, Mimasaka province & Temple K & $1853-1910$ & 3,862 \\
\hline Sanjou village, Mitsugi County, Bingo province & Temple L & $1829-1863$ & 708 \\
\hline Fussa village, Tama County, Musashi province & Temple M & $528^{*}-1910$ & 2,900 \\
\hline \multicolumn{1}{c}{ Total } & & & 3,3853 \\
\hline
\end{tabular}

"Very old records usually refer to the death of high priests. Records concerning lay people started to be mentioned in the Buddhist temple death registers around the 17th century.

\section{(3) Application Programs}

The application programs provide 51 demographic statistics and indicators as listed below. The user interface has the same structure as the application programs in the data analysis system for the religious investigation registers.

1) Number of deaths indicators

Number of deaths by sex, number of male deaths, number of female deaths, sex ratio at death, number of deaths by date of death and sex, percentage of deaths by date of death and sex, sex ratio at death by date of death, number of deaths with death places, percentage of deaths with death places, number of deaths with birthplaces, percentage of deaths with birthplaces, number of deaths with residence, percentage of deaths with residence.

2) Age at death indicators

Number of deaths by last words of posthumous Buddhist name, percentage of deaths by last words of posthumous Buddhist name, total number of deaths by age at death and last words of posthumous Buddhist name, number of infant and child deaths by age at death and last words of posthumous Buddhist name, number of adult deaths by age at death and last words of posthumous Buddhist name, number of priest deaths by age at death and last words of posthumous Buddhist name, number of infant and child deaths by last words of posthumous Buddhist name, number of adult deaths by last words of posthumous Buddhist name, number of priest deaths by last words of posthumous Buddhist name, number of deaths by age groups, number of infant and child deaths, number of adult deaths, sex ratio at death by age groups.

3) Seasonality of deaths indicators

Number of deaths by months and sex, percentage of the deaths by months and sex, sex ratio at death by months, number of deaths by months and age groups, percentage of deaths by 
months and age groups, sex ratio at death by months and age groups, number of deaths by seasons and sex, percentage of deaths by seasons and sex, sex ratio at death by seasons, number of deaths by seasons and age groups, percentage of deaths by seasons and age groups, sex ratio by seasons and age groups.

4) Cause of death indicators

Number of deaths with cause of death, percentage of deaths with cause of death, number of miscarriages and stillbirths by sex, number of miscarriages and stillbirths by posthumous Buddhist name, number of deaths from smallpox by sex, ages at deaths from smallpox, number of deaths with date of birth, percentage of deaths with date of birth, number of deaths with the date of death, percentage of the deaths with the date of death, number of deaths with age at death, percentage of deaths with age at death.

\section{Data Analysis System for the Household Registers}

\section{(1) Source Documents}

The third kind of documents for population and family studies in the mid 19th century are the household registers called Koseki, which were first established in the 1870s. Both Wakamatsu Prefecture including Aizu County and Ohnuma County as well as Kanagawa Prefecture including Tama County abolished the religious investigation registers and started to compile 'new' household registers in 1870. The Wakamatsu and Kanagawa Prefecture administrative offices followed the household register model in accordance with the household register law-KosekiShihoh-which was enacted on October 28, 1868 in Kyoto Prefecture.

Every village head-Kimoiri-in Wakamatsu Prefecture established the household registers from March to June 1870. The household registers provide, for each person, the following information : first name, age, relationship with the head of the household, and change in family status. For each household the following items are recorded: number of cattle and horses, size of the paddy fields, size of the plowed fields, size of the forests, size of the premises, number of Japanese lacquer trees, religious sect, family temple, place of the family temple, side activities, and household size.

We verified the 1868 and 1869 religious investigation registers as well as the 1870 and 1871 household registers in the village of Kuwanohara, in Ohnuma County. We were able to verify all the heads of households, the household members, the ages, the relationship with the head of the household and the family temples, as well as changes in family status. Therefore, it seems that at least in Wakamatsu Prefecture, the transition from the religious investigation registers to the household registers was carried out smoothly.

Village heads-Nanushi-in Kanagawa Prefecture also established household registers in December 1870. In addition to the data in the household registers of Wakamatsu Prefecture, records also mention family name, yield of paddy fields, yield of plowed fields, and yield of forests. Family temple, place of the family temple, and religious sect were not mentioned in the registers. The household register in one village comprised four parts : household register of common people, household register of Shinto priests, household register of Buddhist priests, and household register of servants. We found some regional variations in the format of the 1870 household registers.

If we succeeded in finding a large number of household registers in several other regions, it would be possible to compare regional characteristics of population and household structures at 
the beginning of the population growth in the mid 19th century. Furthermore, in Wakamatsu and Kanagawa Prefectures, family members who moved out from their parent's house for marriage, adoption, apprenticeship, etc. before 1870, were entered in both their original household registers and the new household register. Therefore, the household registers are very important to investigate internal migration.

\section{(2) Database}

We have collected household registers of 52 villages in Aizu County, Ohnuma County and Tama County and stored up approximately 12,000 personal data and 1,800 household data (Table 3).

The household registers database is composed of three tables: personal information table, household information table, and bibliography table. The user interface has nearly the same structure as the database in the data analysis system for the religious investigation registers. There is no digital image form in this database. All data are in UTF-8 Character Set. Items in bold letters represent numerical values and the other items are recorded in kanji code as follows :

1) Personal information table

Village/county/province, latitude, longitude, year, household ID number, personal ID number, name in Roman letters, name in Chinese characters, sex, age, relationship with the head of the household, marital status, religion, place of the family temple, family temple, change in family status, details concerning the change in family status, official status in the village.

2) Household information table

Village/county/province, latitude, longitude, year, household ID number, name of the head in Roman letters, name of the head in Chinese characters, number of male kin members, number of female kin members, number of hereditary male servants, number of hereditary female servants, number of male servants, number of female servants, number of male lodgers, number of female lodgers, household size, structure of household, existence of other persons in addition to the kin members, generations living together, number of cattle, number of horses, size of the paddy fields, yield of paddy fields, size of the plowed fields, yield of plowed fields, size of the premises, yield of the premises, size of the forests, yield of forests, side activities, guardian deity.

3) Bibliography table

Village/county/province, year, date of registration according to the Japanese old lunar calendar, title of the register, name of the person who made the register, owner of the household registers.

\section{(3) Application Programs}

The application programs provide 52 demographic statistics and indicators as listed below. The user interface has the same structure as the application programs in the data analysis system for the religious investigation registers.

1) Population structure indicators in the village

Population, sex ratio, number of cattle and horses, population by five-year age groups, percentage of population by five-year age groups, population aged 14 and under, 15-59, 60 and above, sex ratio of the population aged 14 and under, 15-59, 60 and above, percentage of 
Table 3. Household Registers in DANJURO

\begin{tabular}{|c|c|c|c|}
\hline Village/county/province & Year & Number of persons & Number of households \\
\hline Iyodo village, Aizu County, Iwashiro province & 1871 & 80 & 14 \\
\hline Terayama village, Aizu County, Iwashiro province & 1871 & 25 & 5 \\
\hline Komatsukawa village, Aizu County, Iwashiro province & 1871 & 107 & 18 \\
\hline Iwashita village, Aizu County, Iwashiro province & 1871 & 31 & 10 \\
\hline Naka-arai village, Aizu County, Iwashiro province & 1874 & 326 & 61 \\
\hline Kawashima village, Aizu County, Iwashiro province & 1874 & 279 & 61 \\
\hline Sekimoto village, Aizu County, Iwashiro province & 1874 & 103 & 25 \\
\hline Noshido village, Aizu County, Iwashiro province & 1876 & 107 & 24 \\
\hline Nagano village, Aizu County, Iwashiro province & 1878 & 714 & 93 \\
\hline Nakazaike village, Ohnuma County, Iwashiro province & 1871 & 47 & 9 \\
\hline Kami-Sugihara village, Ohnuma County, Iwashiro province & 1870 & 126 & 20 \\
\hline Kami-Sugihara village, Ohnuma County, Iwashiro province & 1871 & 131 & 21 \\
\hline Naka village, Ohnuma County, Iwashiro province & 1871 & 17 & 3 \\
\hline Niou village, Ohnuma County, Iwashiro province & 1870 & 68 & 14 \\
\hline Niou village, Ohnuma County, Iwashiro province & 1871 & 78 & 16 \\
\hline Iriyachi village, Ohnuma County, Iwashiro province & 1871 & 50 & 9 \\
\hline Ooiwa village, Ohnuma County, Iwashiro province & 1871 & 55 & 10 \\
\hline Koyama village, Ohnuma County, Iwashiro province & 1870 & 119 & 20 \\
\hline Koyama village, Ohnuma County, Iwashiro province & 1871 & 131 & 21 \\
\hline Ogawakubo village, Ohnuma County, Iwashiro province & 1871 & 187 & 35 \\
\hline Matsugishi village, Ohnuma County, Iwashiro province & 1871 & 348 & 60 \\
\hline Kuwanohara village, Ohnuma County, Iwashiro province & 1870 & 149 & 25 \\
\hline Kuwanohara village, Ohnuma County, Iwashiro province & 1871 & 151 & 25 \\
\hline Ebiyama village, Ohnuma County, Iwashiro province & 1870 & 35 & 6 \\
\hline Ebiyama village, Ohnuma County, Iwashiro province & 1871 & 37 & 6 \\
\hline Suganuma village, Ohnuma County, Iwashiro province & 1870 & 21 & 4 \\
\hline Suganuma village, Ohnuma County, Iwashiro province & 1871 & 22 & 4 \\
\hline Ochiai village, Ohnuma County, Iwashiro province & 1870 & 81 & 15 \\
\hline Ochiai village, Ohnuma County, Iwashiro province & 1871 & 106 & 20 \\
\hline Uobuchi village, Ohnuma County, Iwashiro province & 1871 & 191 & 36 \\
\hline Mogusa village, Tama County, Musashi province & 1870 & 381 & 47 \\
\hline Hirayama village, Tama County, Musashi province & 1870 & 867 & 121 \\
\hline Koshino village, Tama County, Musashi province & 1870 & 250 & 45 \\
\hline Bessho village, Tama County, Musashi province & 1870 & 166 & 28 \\
\hline Kaidori village, Tama County, Musashi province & 1870 & 331 & 44 \\
\hline Sekido village, Tama County, Musashi prone & 1870 & 328 & 43 \\
\hline Ichinomiya village, Tama County, Musashi province & 1870 & 310 & 41 \\
\hline Ochiai village, Tama County, Musashi province & 1870 & 576 & 83 \\
\hline Manganji village, Tama County, Musashi province & 1870 & 194 & 24 \\
\hline Teragata village, Tama County, Musashi province & 1870 & 349 & 51 \\
\hline Kamida village, Tama County, Musashi province & 1870 & 76 & 13 \\
\hline
\end{tabular}




\begin{tabular}{l|c|c|c}
\hline Kawabe-Horinouchi village, Tama County, Musashi province & 1870 & 290 & 43 \\
\hline Kotta village, Tama County, Musashi province & 1870 & 489 & 69 \\
\hline Takahata village, Tama County, Musashi province & 1870 & 251 & 33 \\
\hline Ohtsuka village, Tama County, Musashi province & 1870 & 496 & 32 \\
\hline Arai village, Tama County, Musashi province & 1870 & 287 & 66 \\
\hline Nakano village, Tama County, Musashi province & 1870 & 472 & 51 \\
\hline Wada village, Tama County, Musashi province & 1870 & 344 & 56 \\
\hline Taira village, Tama County, Musashi province & 1870 & 586 & 51 \\
\hline Ohsawa village, Tama County, Musashi province & 1870 & 380 & 40 \\
\hline Matsugi village, Tama County, Musashi province & 1870 & 399 & $\mathbf{1 , 8 3 0}$ \\
\hline Ochikawa village, Tama County, Musashi province & 1870 & 317 & $\mathbf{1 2 , 0 6 1}$ \\
\hline \multicolumn{1}{c}{ Total } & & & 56 \\
\hline
\end{tabular}

the population aged 14 and under, 15-59, 60 and above, population by marital status, percentage of population by marital status, population by religion, percentage of population by religion.

2) Population structure indicators in the county

Population, sex ratio, number of cattle and horses, population by five-year age groups, percentage of population by five-year age groups, population aged 14 and under, 15-59, 60 and above, sex ratio of the population aged 14 and under, 15-59, 60 and above, percentage of the population aged 14 and under, 15-59, 60 and above, population by marital status, percentage of population by marital status, population by religion, percentage of population by religion.

3) Household structure indicators in the village

Household mean size, number of households by household size, percentage of households by household size, number of households by generations living together, percentage of households by generations living together, number of households by their structure, percentage of households by their structure, number of households with cattle and horses, percentage of households with cattle and horses, number of households by yield of cultivated land, percentage of households by yield of cultivated land, number of households with servants, percentage of households with servants.

4) Household structure indicators in the county

Household mean size, number of households by household size, percentage of households by household size, number of households by generations living together, percentage of households by generations living together, number of households by their structure, percentage of households by their structure, number of households with cattle and horses, percentage of households with cattle and horses, number of households by yield of cultivated land, percentage of households by yield of cultivated land, number of households with servants, percentage of households with servants.

\section{The Alliance Project for Kinship and Genealogy}

With the collaboration of Professor Shigenobu Sugito, we are developing another computer 


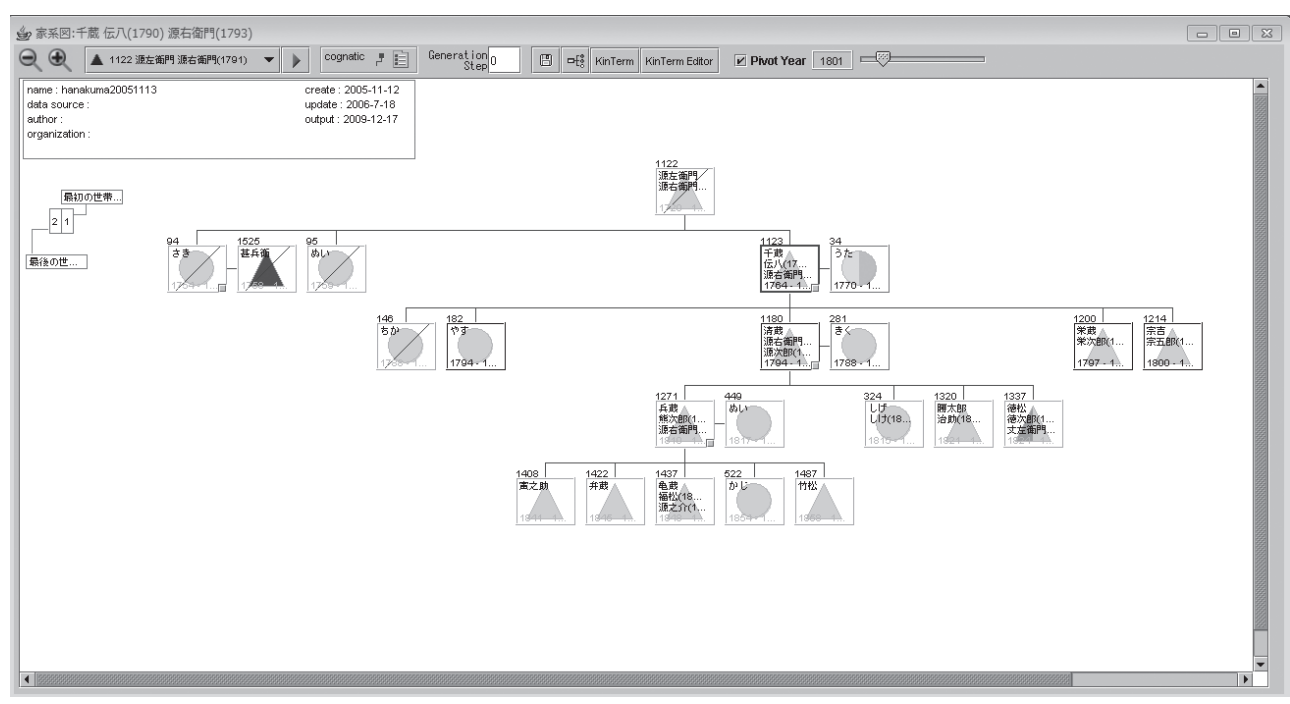

Figure 3. Genealogy of the Genuemon Family in the Village of Hanakuma

system to analyze kinship and genealogy. In this project, we attempt to propose a new framework for family studies by investigating personal blood or non-blood relationship in genealogy, instead of households as recorded in the religious investigation registers.

Professor Sugito made a program to convert the personal information data in the database of the religious investigation registers in DANJURO for the Alliance data. After the conversion, Alliance can display large kinship genealogies with Java programs and HSQLDB, which is a free database management system with Java, on any operating systems for personal computers. Users can choose either patrilineal or matrilineal lines. The trace route function enables to establish the relationship between two persons. The pivot year switch is convenient to differentiate persons alive from those dead or absent in a particular year. In Figure 3, Alliance shows dead or absent persons with a slanting line and children yet to be born in light blue color, in the patrilineal genealogy of the Genuemon family in 1801.

With the Alliance system, it will probably be possible to find the role of kinship in a wedding ceremony, a birth celebration, a funeral service and so on. We also expect that this system will help to clarify the role of kinship in marriage, adoption, inheritance, etc. in the near future.

\section{The Historical GIS Project for Geographic Mobility}

One of the most significant features of the religious investigation registers is the detailed description of internal migrants. We can verify the places of departure of brides, bridegrooms and servants. Also, it is sometimes possible to find the places of destination of the daughters, sons and servants. We have started to develop a historical GIS with Professor Tsunekazu Kato, in order to investigate geographic mobility with the database of the religious investigation registers in DANJURO'.

Dr. Kato developed the source program of the original HGIS with Visual Basic 6.0 for Microsoft Windows XP. The size of the execution program on this system is $614 \mathrm{~KB}$. The base map of the HGIS is a digital map of 50 m grids (elevation). He digitized the old coastline from the 


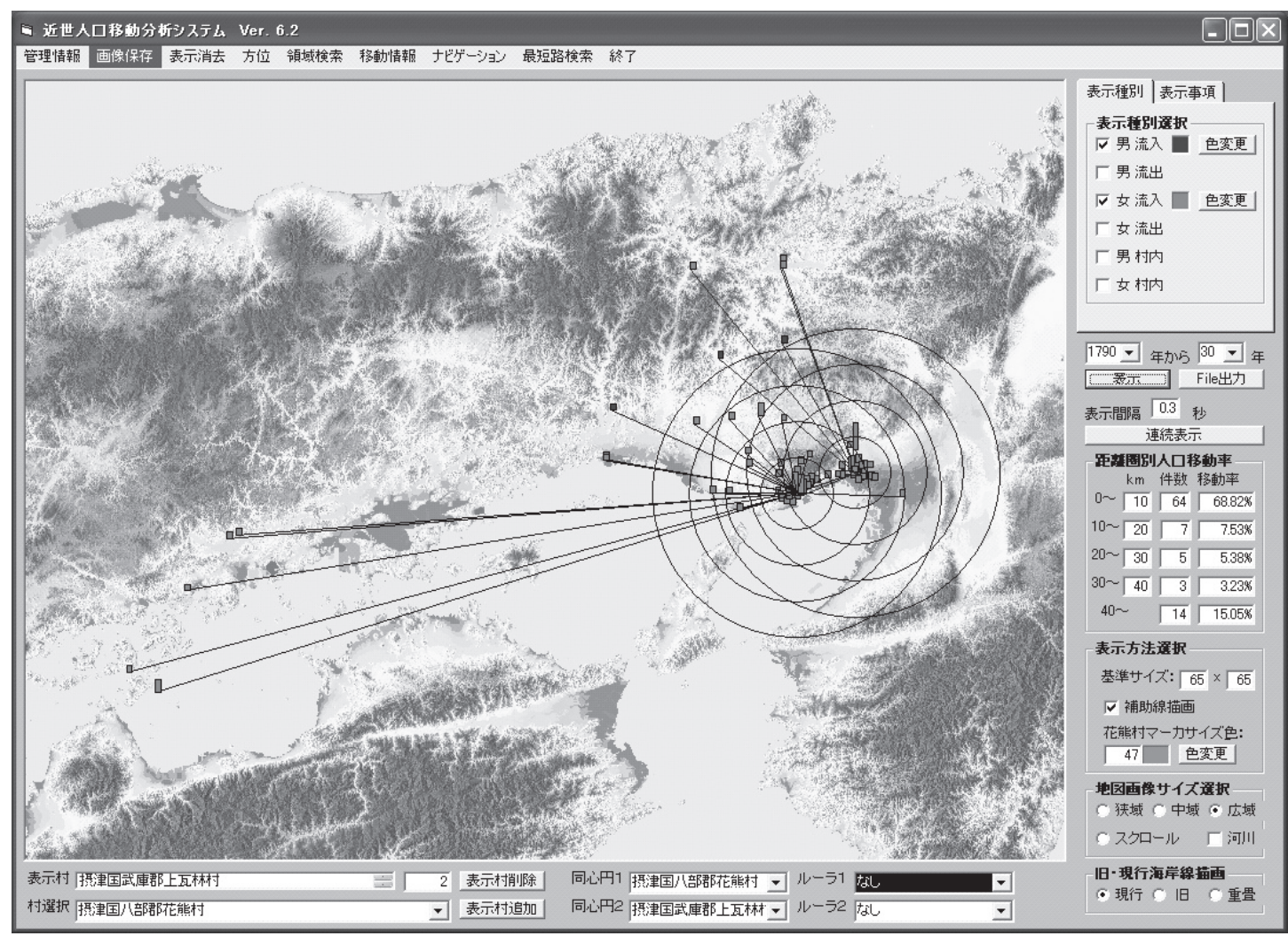

Figure 4. Migrations for Marriage into Hanakuma and Kami-Kawarabayashi

Shusei maps $(1: 200,000)$ established in the 1880s and he added latitude and longitude data on the coastline dating back 120 years. Then he overlaid the old coastline on the digital map of $50 \mathrm{~m}$ grids (elevation) and colored the area between the old and the current coastlines in light blue.

With the recent version of the HGIS, it is possible to show the places of departure and destination of internal migrants by cause of migration, including marriage, adoption, housemoving, apprenticeship, etc. We can choose any period of time and show the distribution map continuously, at any time period. It is also possible to draw concentric circles with a radius of any distance and count the number of migrants within each concentric circle.

Figure 4 is a distribution map of the departure places of brides and bridegrooms who married inhabitants of the village of Hanakuma in Yatabe County and the village of Kami-Kawarabayashi in Muko County, from 1790 to 1819 . Both villages are located on the Osaka Plain. Four concentric circles with a radius of 10, 20, 30 and $40 \mathrm{~km}$ are drawn in Figure 4 . We were able to verify that during a period of thirty years, approximately $15 \%$ of brides and bridegrooms married into Hanakuma or Kami-Kawarabayashi from a distance of over $40 \mathrm{~km}$. Those brides and bridegrooms crossed some wide rivers, high mountains and even the Inland Sea. They also crossed boundaries of counties, provinces and local lords' domains in order to get married in Hanakuma or Kami-Kawarabayashi. Long-distance marriages from rural districts to urban areas and their suburbs were not unusual before the industrial revolution.

In the next version of the HGIS, we envisage showing the borders of counties and provinces in early modern Japan, in order to evaluate the effects of administrative boundaries on the peasants' 
migration patterns. We also intend to restore the topography of early modern Japan and to assess the effects of natural obstacles such as wide rivers, the Inland sea and mountains on migration.

\section{Geographical Use of the System : Regional Difference in Women's Age at Marriage}

Recently, Professor Akira Hayami pointed out the regional variations in the real life-paths of the peasants. It is important to consider regional patterns in reproductive behavior placed in a background of regional differences, in order to understand the peasants' real life in early modern Japan. With DANJURO, we have calculated the mean age of women at first marriage in six villages, as it has probably an important influence on the structure of households, the retirement patterns from a household headship, number of births, etc. (Table 4).

The mean age of women at first marriage in four villages in Aizu County and Ohnuma County in the province of Mutsu are nearly the same. On the other hand, their mean age at first marriage, in two villages in the province of Settsu, is also very close. However, the mean age at first marriage in Aizu and Ohnuma is four to eight years earlier than in two villages on the Osaka Plain.

In order to verify the influence of the mean age of women at first marriage on the household structures, we tried to compare the percentage of simple family households against multiple family households in six villages (Figure 5,6). Following the schema in the important work Household and Family in Past Times by Professor Peter Laslett, we divided the households into five categories: single persons, no family, simple family households, extended family households, multiple family households, and indeterminate cases.

In Hanakuma and Kami-Kawarabayashi, the percentage of simple family households was relatively stable, as it stood at 50 to $70 \%$. The percentage of multiple family households was quite stable too, standing at 5 to $20 \%$. From 1750 to 1870 , simple family households were typical in the villages located on the Osaka Plain. On the other hand, the percentage of multiple family households was between 20 and 60\% in Kuwanohara, Komatsukawa, Tounosu, and Ishibuse. These figures are above the percentage of simple family households, which was between 10 and $45 \%$. The percentage of simple family households in two villages on the Osaka Plain was always above the percentage in four villages in the northeastern mountainous region. On the contrary,

Table 4. Mean Age of Women at First Marriage

\begin{tabular}{l|c|c|c}
\hline \multicolumn{1}{c|}{ Village } & Births dates & Number of brides & Mean age at first marriage \\
\hline Ishibuse & $1752-1771$ & 13 & 16.4 \\
\hline Tounosu & $1790-1809$ & 21 & 19.3 \\
& $1810-1829$ & 31 & 19.4 \\
\hline Komatsukawa & $1792-1811$ & 11 & 19.4 \\
\hline Kuwanohara & $1750-1769$ & 15 & 18.7 \\
& $1770-1789$ & 10 & 21.5 \\
& $1790-1809$ & 18 & 19.3 \\
\hline Kami-Kawarabayashi & $1750-1769$ & 38 & 22.4 \\
& $1770-1789$ & 38 & 25.4 \\
\hline Hanakuma & $1789-1808$ & 27 & 26.4 \\
& $1809-1828$ & 28 & 27.4 \\
\hline
\end{tabular}

Source: DANJURO ver.4.0 (http://kawaguchi.tezukayama-u.ac.jp (10 November 2009)) 


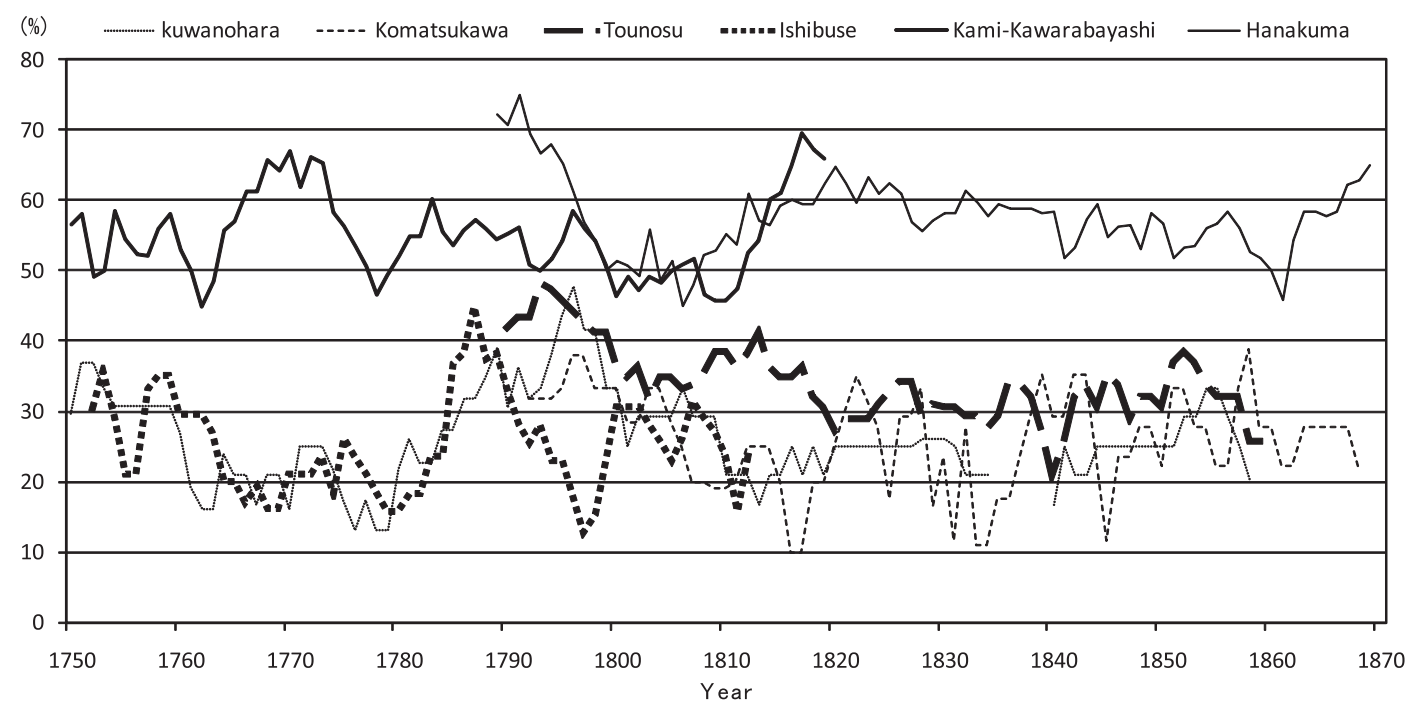

Figure 5. Percentage of Simple Family Households

Source: DANJURO ver.4.0 (http: // kawaguchi. tezukayama-u. ac.jp (10 Novenber 2009))

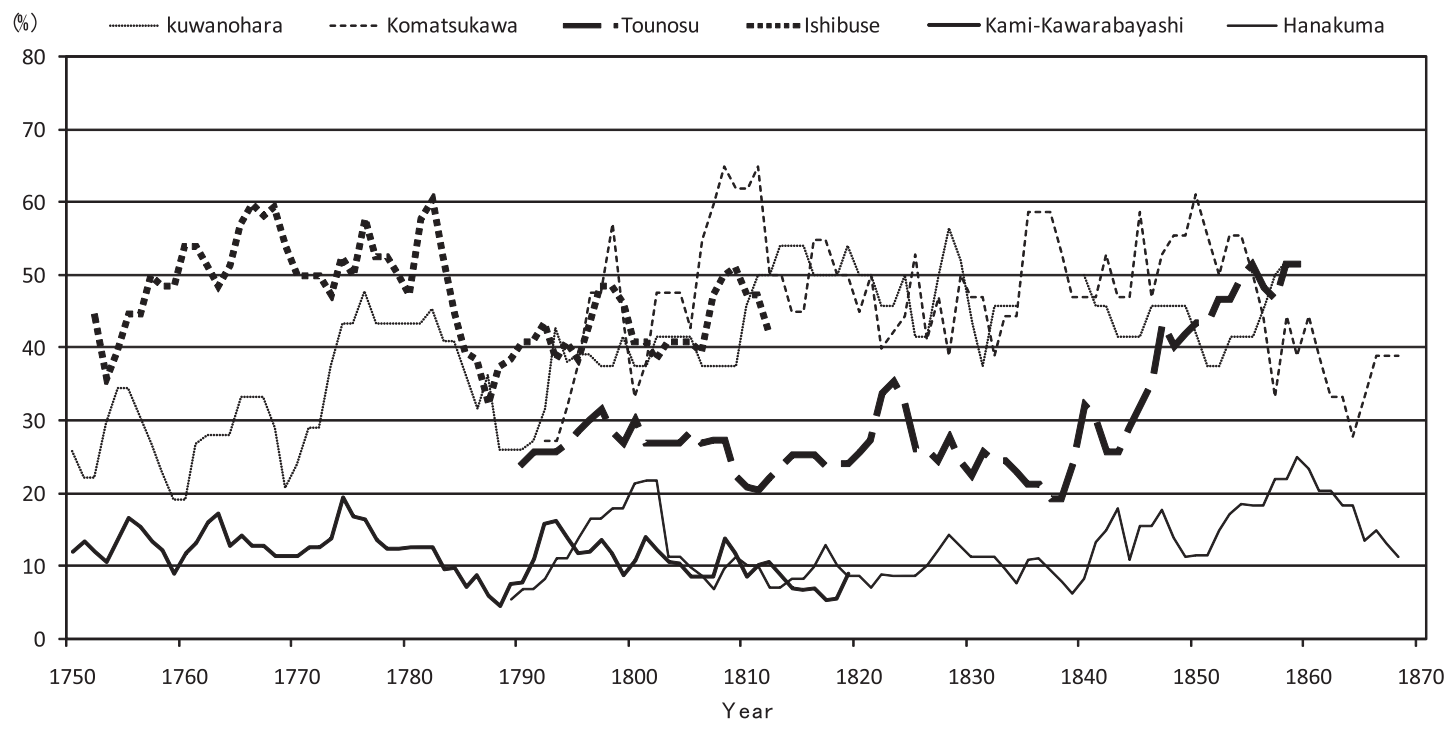

Figure 6. Percentage of Multiple Family Households

Source: DANJURO ver.4.0 (http: // kawaguchi. tezukayama-u. ac.jp (10 Novenber 2009))

the percentage of multiple family households in the four villages in Aizu and Ohnuma was always above the percentage found in the two villages on the Osaka Plain. Therefore, it may be suggested that the mean age at first marriage had an important influence on the household structures in the two regions.

The household structures in both Aizu and Ohnuma were not stable during a period of 120 years from 1750. Particularly, the percentage of simple family households increased rapidly after the 1783 great famine in Kuwanohara and Ishibuse and probably as well in Tounosu and Komatsukawa. It seemed to decrease gradually after 1795 . On the other hand, the percentage of 


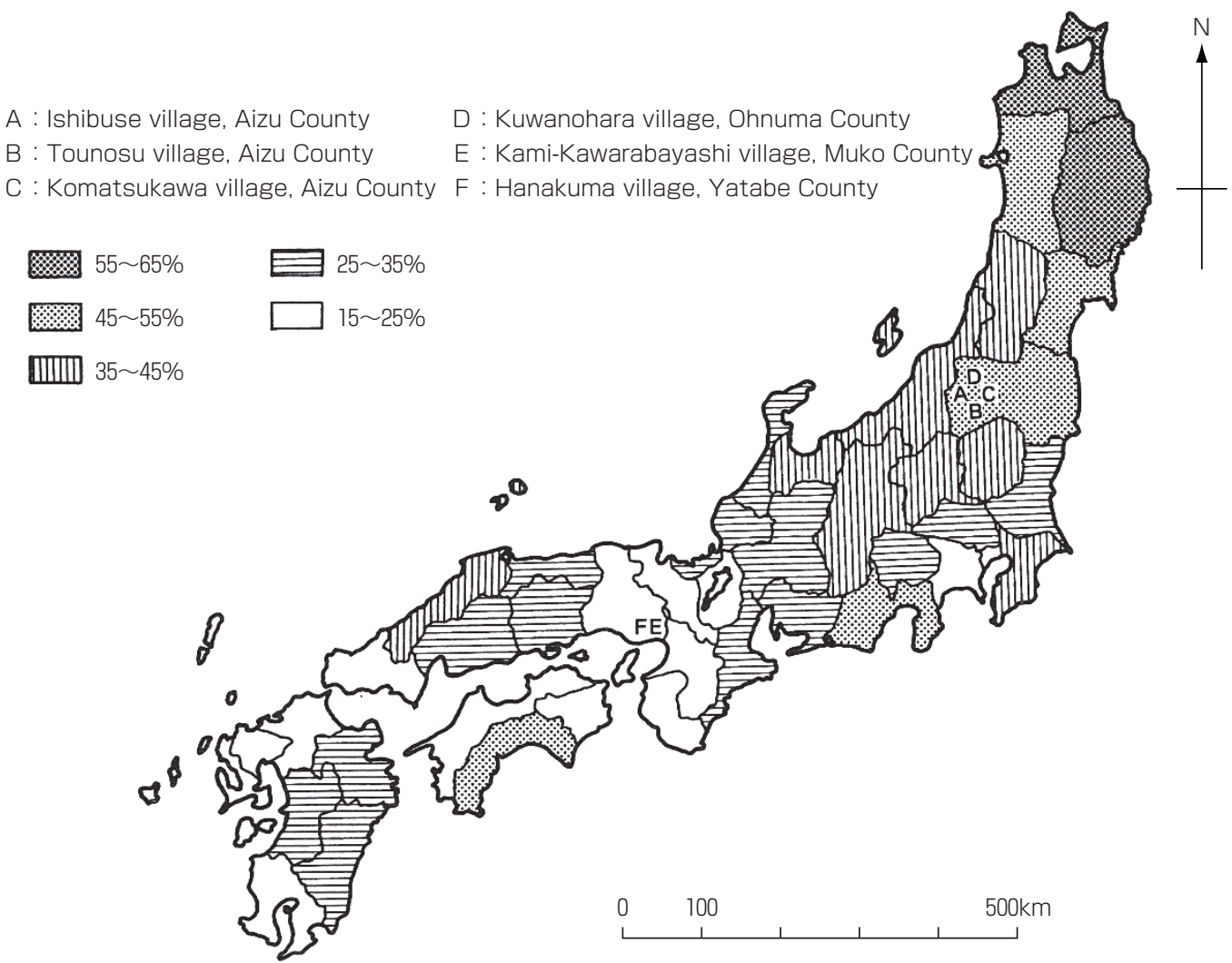

Figure 7. Percentage of Women Married at the Age of Twenty in 1886

Source: The family Registration Section of the General Affairs Bureau, Ministry of Home Affairs, Meiji 19 Nen Nihon Teikoku Minseki Kokoh Hyo, 1886

multiple family households decreased rapidly after the 1783 great famine in Ishibuse and Kuwanohara, while it seemed to increase after 1790 in Komatsukawa, Kuwanohara and Ishibuse. In Tounosu, multiple family households started to increase after 1840. It is therefore certain that the 1783 famine had an important influence on the changes in the family patterns.

In addition to the 1783 great famine, in northeastern Japan there were at least two other serious famines in 1755 and in the 1830s. Although we can scarcely find data about the influence of these two famines in the four villages in figure 5 and 6 , it is possible to imagine that the villages located in Aizu and Ohnuma probably suffered more or less damage, depending on the severity of the famines in the area.

Although we have to consider differences in the household structures by social class, it is possible that a multiple family household, which usually originated from early marriage, was the basic structure, and environmental factors such as cold weather, famines or economic status, etc. had a transitory influence on the household structures before the end of the 19th century in this region. Early marriage and multiple family households seemed to be quite flexible against severe environmental factors.

We included in DANJURO the six villages, in the 1886 national population statistics on marital status by age. In Figure 7, we could verify the regional differences in women's age at marriage: early marriage in northeastern Japan and late marriage in central Japan including two urban 
regions and southwestern Japan. In northeastern Japan, the percentage of women married at the age of twenty was over $45 \%$. Conversely, it was under $25 \%$ in the southern part of the Kanto Region, the Kinki Region, the northern part of Shikoku, and the North of Kyushu. Although we have been able to examine the data only in six small villages, these data probably demonstrate the regional differences in women's age at marriage and household structures since the 18th century.

\section{Conclusion}

In order to establish a bridge between early modern society and contemporary society in Japan from the perspective of population and family studies, we are well aware that it has become urgent to analyze regional patterns of reproductive behavior to reconstruct the changes in the reproductive pattern over the years. To that end, it is necessary to develop a database system to collect, store, and analyze historical documents and share the system with researchers around the world through the Internet.

We have been developing the DANJURO data analysis system for population and family studies on Japan from the 17th to the 19th century, with the help of historical handwritten documents. DANJURO has allowed us to improve four technical problems : to reduce data processing to output demographic statistics and indicators, to ensure the reliability of the data processing, to preserve historical documents in digital form, and to share the data and data analysis methods with researchers around the world.

DANJURO has six parts of which the data analysis systems for the religious investigation registers, the Buddhist temple death registers and the household registers constitute the core of the system. It also contains pages concerning technology to recognize handwritten characters in historical documents with neural network, research funds and publication of research results, as well as links to other related sites. We have started to develop now with DANJURO the Alliance system for genealogy and kinship studies and the historical GIS for internal migration. We intend to provide both systems through the Internet in the near future.

The DANJURO system has also allowed us to find regional differences in mean age of women at first marriage and in household structures between Aizu County and Ohnuma County in the province of Mutsu, and Muko County and Yatabe County in the province of Settsu. In both regions, we were able to verify long-distance marriages from the end of the 18th century. It is clear that the reproductive behavior in each village was not limited to nearby villages where peasants could make a round trip in one day. Therefore, it is necessary to collect, store and analyze additional series of historical registers with DANJURO and to place the population characteristics of each small village in a nationwide perspective.

\section{Acknowledgement}

I wish to express my sincere gratitude to the associate researchers of the DANJURO Project: Professors Kunihiko Uehara and Shinji Hioki at Tezukayama University; Professor Shigenobu Sugito at Sugiyama Jyogakuen University; Professor Tsunekazu Kato at Osaka ElectroCommunication University; Professor Satomi Kurosu at Reitaku University. I also thank the proofreaders : Professor Fusako Ogata at Tezukayama University and Ms. Michiko Tanaka. This project was supported by the Japanese Society for Promotion of Science (JSPS Grant-in-Aid for Scientific Research, B, No. 21300098, fiscal years 2009-2012). This paper was presented at the 14th 


\section{International Conference of Historical Geographers at Kyoto University, in August 2009.}

\section{Notes}

1) Kito, H., Jinkou de Miru Nihon-Shi, PHP Interface, 2007, P. 10. (J)

2) (1) Kawaguchi, H., 'Population trend and infanticide in a rural area in north-eastern Japan from the 17th to the 19th century', The Historical Geography, 40(5), 1998, pp. 5-25. (JE) (2) Takagi, M., ed., $18 \cdot 19$ Seiki no Jinkoh Hendoh to Chiiki $\cdot$ Mura $\cdot$ Kazoku, Kokon Shoin, 2008. (J)

3) Hayami, A., The historical demography of Pre-modern Japan, University of Tokyo Press, 2001.

4) Hayami, A. and Yasumoto, M., 'Family Reconstitution in Historical Demography', Socio-economic History, 34 (2), 1968, pp. 123-158. (JE)

5) Kawaguchi, H. and Nakayama, K., 'The development of DANJURO (Demographic Analysis system in Japan using relational database of Shumon-Aratame-Cho) ', (Nihon Gakujyutsu Kaigi, ed., Proceedings of Joho Gaku Symposium 1989, 1989), pp. 125-134. (J)

6) (1) Ono, Y., 'A computer utilization on humanities II : user interface for data entry (a case of historical demography) ', Bulletin of International Research Center for Japanese Studies, 8, 1993, pp. 165-182. (JE) (2) Morimoto, S., 'The creation of a database for statistical analysis of "Shumon Aratame Cho", Bulletin of International Research Center for Japanese Studies, 19, 1999, pp. 265-276. (JE)

7) (1) Kawaguchi, H., 'Constructing a demographic database system for analyzing the Japanese religious investigation registers', (Raghavan, V. and Hien, H., ed., Proceedings of International Symposium on Geo-Informatics for SpatialInfrastructure Development in Earth and Allied Sciences 2002, 2002), pp. 89-95. (2) Kawaguchi, H., 'Demographic analyzing system in Tokugawa Japan using the relational database of historical documents (DANJURO ver. 2.0) ; Tezukayama Academic Review, 9, 2002, pp. 1-27. (JE)

8) Fujita, S., 'Aizu Han ni okeru Bukkyo Tousei no Kakuritsu', Fukushima-Ken Rekishi-Shiryou-Kan Kenkyu-Kiyo, 3, pp. 15-56, 1981. (J)

9) Kawaguchi, H., 'The development of a historical demographic database system for analyzing the Shumon-

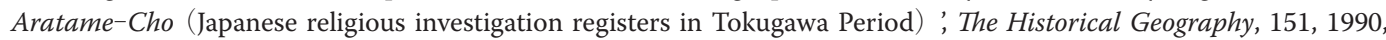
pp. 16-33. (JE)

10) (1) Ohishi, S., Kinsei Sonraku no Kouzou to Ie Seido, Ochanomizu Shobo, 1977. (J) (2) Tanaka, K., Mura kara Mita Nihon-Shi, Chikuma Shobo, 2002. (J)

11) The religious investigation registers was carefully examined in some papers by EAP Project members. (1) Higashi, N., 'Shumon-Aratame-Cho no Sakusei-Okayama Han no Shumon-Aratame-Cho no Hensen-', Okayama Chihoushi Kenkyu, 82, 1997, pp. 1-10 (J) (2) Hirai, S., Nihon no Kazoku to Raifu Kosu-Ie Seisei no Rekishi Syakaigaku-, Minerva, 2008. (J) (3) Morimoto, K., Senzo Saishi to Ie no Kakuritsu, Minerva, 2006. (J) (4) Matsuura, A., 'The Pattern of Rule and the Title of Shumon Aratame', Journal of Political Economy and Commercial Science, 189 (1), 2004, pp. 1-19. (JE) (5) Takagi, M., ed., Kuukan to Idou no Rekishichiri, Ritsumeikan University, 2001. (J)

12) Ohshiba, H., 'Population and social background of deceased people listed in the Kakocho in Mikami area of Omi Province since eighteenth Century', The Journal of population studies, 24, 1999, pp. 57-66. (JE)

13) Maruyama, H. and Matsuda, T., 'Problems on historical demography', Human Ecology and Race Hygiene, 42 (5), 1976, pp. 227-235. (J)

14) Kawaguchi, H., 'Musashi no Kuni Tama Gun no Jiin Kako-Cho ni Kiroku Sareteiru Kodomo no Kaimyo', Toukei, 60 (6), 2009, pp. 17-23. (J)

15) (1) Kikuchi, K., Nihon no Rekishi Saigai-Edo Jidai no Kikin, Kokon Shoin, 1980. (J) (2) Kawaguchi, H., 'Decrease of child deaths from smallpox after the introduction of vaccination on the outskirts of Edo (Tokyo), Japan', (Kurosu, S., Bengtsson, T., and Campbell C., ed., Proceedings of the IUSSP Seminar, 2009; Demographic Responses to Economic and Environmental Crises, Reitaku University, 2010), pp. 252-271.

16) Kawaguchi, H., 'Sex ratio and family structure in Minamiyama-Okurairi District, Mutsu Province in northeastern Japan in 1871', Bulletin of Tsukuba Junior College, Tokyo Kasei Gakuin, 2 (1), 1992, pp. 99-119. (JE)

17) Kawaguchi, H., Uehara, K. and Hioki, S., 'Application programs for analyzing the Japanese family registers in the 1870s', IPSJ Symposium Series, 2009 (16), 2009, pp. 79-86. (JE)

18) The application programs providing household structure indicators in the village and in the county are under construction, They will be set before April, 2010.

19) Sugito S., 'Possibility of lineage study in demography', The Journal of population studies, 34, 2004, pp. 23-29. (JE)

20) Sugito, S. and Kawaguchi, H., 'An approach to the kinship in Tokugawa Japan with the Alliance database system on Japanese religious investigation registers', IPSJ Symposium Series, 2005 (21), 2005, pp. 159-166. (JE)

21) Sugito, S., 'Anthropological Fieldwork Tool, Alliance, the Kinship Database and Genealogy', Newsletter of Japanese Society for Oceanic Studies, 86, 2006, pp. 10-32. (JE)

22) Nakajima, T. and Kato, T., 'Applications of a support system for drawing distribution maps', IPSJ Symposium Series, 
2006 (17), 2006, pp. 87-94. (JE)

23) Kato, T., 'Consideration on digital use of Shusei Maps', IPSJ SIG Technical Reports, 2007 (49), 2007, pp. 73-80. (JE)

24) Kawaguchi, H. and Kato, T., 'Data analysis system for historical demography in Tokugawa Japan', (Proceedings of Historical Maps and GIS 2007, Nagoya University, 2007), pp. 23-29.

25) Kawaguchi, H., 'Long distance marriage in the Kinki District, the $17^{\text {th }}-19^{\text {th }}$ Centuries', The Historical Geography, 140, 1988, pp. 1-16. (JE)

26) Hayami, A., Historical demography of early-modern Japan, Fujiwara Shoten, 2009. (J)

27) Laslett, P., ed., Household and Family in Past Time, 1972, Cambridge University Press, p. 31.

28) Differences in the household structures by social class in Aizu County and Ohnuma County have considered in the following book. Okada, A., Kinsei Sonraku Shakai no Ie to Setai Keisho, Chisen Shokan, 2006. (J)

29) Long-distance marriages from the beginning of the 19th century in Aizu County and Ohnuma County were discussed in the following papers. (1) Kawaguchi, H., 'Population increase policy after the 1783 great famine in northeasters Tokugawa Japan', Annales de Démographie Hitorique, 1996, 1997, pp. 151-168. (2) Kawaguchi, H., 'In-migration plan in Minamiyama-Okurairi-Ryou from the beginning of the 19th Century', En marge de l'histoire, 50, 2005, pp. 17-37. (JE)

\title{
Data Analysis System for Population and Family Studies on Japan in the 17th-19th Centuries
}

\author{
KAWAGUCHI Hiroshi \\ Faculty of Business Administratron, Tezukayama University
}

Most studies on population and family patterns in early modern Japan have been carried out with three kinds of historical documents : the religious investigation registers, the Buddhist temple death registers, and the household registers. In cases where these handwritten documents have been well preserved, we can obtain a considerable amount of information about the real life of peasants including not only population statistics, but also indices concerning family status. We have been developing a database system to calculate demographic statistics from these documents. With this system, we can improve the following four technical aspects : reduction of data processing to output demographic statistics, reliability of the data processing, preservation of historical documents in digital form, and sharing of data and analysis methods with researchers around the world. We named this system DANJURO. We have also started to develop the Alliance system for kinship and genealogy studies, and the historical GIS for geographic mobility with the database in DANJURO. DANJURO allowed us to find regional differences in the mean age of women at first marriage and the structure of households between Aizu/Ohnuma counties and Muko/Yatabe counties. We were also able to verify long-distance marriages in both regions from the end of the 18th century. It is clear that the reproductive behavior in each village was not limited to nearby villages where peasants could make a round trip in one day. Therefore, it is necessary to collect, store, analyze, and share additional series of historical registers with DANJURO and to find the regional patterns of reproductive behavior as well as the reasons for these regional difference in a nationwide perspective before preparing the national demographic statistics.

Keywords : religious investigation register, Buddhist temple death register, household register, genealogy, database, historical GIS 